\title{
Economic Viability of Red Cabbage Production under Varying Environment and Ferti-Irrigation Regimes
}

\author{
Vishal Pandey $^{1 *}$ and N. N. Firake ${ }^{2}$ \\ Dr. A. S. College of Agricultural Engineering and Technology, \\ Mahatma Phule Krishi Vidyapeeth, Rahuri-413 722, India \\ *Corresponding author
}

\section{A B S T R A C T}

Ke y w o r d s
Red cabbage,
Polyhouse, Open
field, Cost of
cultivation, Net
income, B:C ratio
Article Info
Accepted:
15 March 2020
Available Online:
10 April 2020

Introduction

In order to "Doubling the farmer's income by 2022", Indian Government has started taking several steps. In which maximization of irrigated area, providing fertilizer at lower cost to farmers, development of market of agriculture produce, development and promotion of Agriculture processing plant, maximization of export of agricultural produce, promotion and awareness to grow exotic vegetables in Indian climate etc. are included. This research was conducted under natural ventilated polyhouse and open field on red cabbage to study economic viability in Indian climate.

Murthy et al., (2009) reported that the economic viability of tomato and capsicum under naturally ventilated polyhouse with drip irrigation system was found highly feasible i.e. net present value as Rs.3,23,145/500 m², benefit cost ratio as 1.80 and internal rate of returnas $53.7 \%$ with payback period of less than two years. Laate (2013) reported that under greenhouse miscellaneous receipts were included to value of cucumber sales, total gross revenue increased to $\$ 1,219,411$ or 
$\$ 107.21$ per square metre. Braulio et al., (2010) and Kumar et al., (2017) reported similar results for lettuce, cucumber and capsicum.

\section{Materials and Methods}

This research was conducted at Precision Farming Development Centre, of Mahatma Phule Krishi Vidyapeeth, Rahuri, Maharashtra during late kharif season, 201718. Research site is situated at $19^{0} 47^{\prime} \mathrm{N}$ latitude and $74^{\circ} 37^{\prime} \mathrm{E}$ longitudes at $657 \mathrm{~m}$ above mean sea level.The experiment was carried out in polyhouse and open field in split-split plot design with 18 treatments comprising of two environmental conditions (i.e. Polyhouse and open field), three irrigation regimes (i.e. $0.90,0.75$ and 0.60 ETc) and three fertigation regimes (i.e. 125, 100 and $75 \%$ RD) with three replications. The size of the polyhouse was $25 \times 20 \mathrm{~m}$ and open field was $20 \times 18 \mathrm{~m}$. The size of each raised beds in polyhouse and open field were $2.7 \times 0.75 \mathrm{~m}$ and $4.5 \times 0.75 \mathrm{~m}$, respectively, with $0.3 \mathrm{~m}$ height and $0.5 \mathrm{~m}$ buffer strip was provided between two beds to avoid lateral movement of water from one bed to another. The irrigation water was applied daily to the crop through drip irrigation system and soluble fertilizers were applied by using ventury tube assembly. The irrigation scheduling was done as per treatment on the basis of ETc. Water soluble fertilizers were scheduled alternate day through drip irrigation as per recommended dose of fertilizer 80:40:40 NPK kg ha ${ }^{-1}$.

The crop evapo-transpiration was calculated, based on FAO Penman-Monteith formula, with MPKV recommended Phule Jal Software. The volume of water to be applied for each treatment plot was computed by the equation $\mathrm{V}=\mathrm{d} \times \mathrm{A}$, where $\mathrm{V}$ is volume of water, lit; $\mathrm{d}$ is depth of water, $\mathrm{mm}$; and $\mathrm{A}$ is area of plot, $\mathrm{m}^{2}$. The time of operation (hr) of drip irrigation system for each treatment was calculated by equation $T_{0}=V /$ q. n. EU, where To is time of operation of drip irrigation unit for respective treatment (hr); V is volume of water to be applied per irrigation, lit; $\mathrm{q}$ is average discharge of emitter in respective treatments, (lph); EU is emission uniformity of drip irrigation unit (0.90) and $\mathrm{n}$ is number of emitter plot $^{-1}$ (Table $1)$.

\section{Results and Discussion}

\section{Cost of cultivation}

The data in respect of cost of cultivation are presented in Table 2. The cost of cultivation per $1008 \mathrm{~m}^{2}$ was highest ( $₹ 1,48,717 /-$ ) in treatments $\mathrm{E}_{1} \times \mathrm{I}_{1} \times \mathrm{F}_{1}$ (i.e. Polyhouse $\mathrm{x} 0.90$ ETc $\mathrm{x} 125 \%$ RDF), $\mathrm{E}_{1} \times \mathrm{I}_{2} \times \mathrm{F}_{1}$ (i.e. Polyhouse $\mathrm{x} 0.75 \mathrm{ETc} \times 125 \% \mathrm{RDF}$ ) and $\mathrm{E}_{1} \mathrm{x}$ $\mathrm{I}_{3} \times \mathrm{F}_{1}$ (i.e. Polyhouse x 0.60 ETc $\times 125 \%$ RDF). The lowest cost of cultivation of per $1008 \mathrm{~m}^{2}$ (₹ 66,419/-) was found in $\mathrm{E}_{2} \times \mathrm{I}_{1} \mathrm{x}$ $\mathrm{F}_{3}$ (i.e. Open field x $0.90 \mathrm{ETc} \times 75 \% \mathrm{RDF}$ ), $\mathrm{E}_{2} \times \mathrm{I}_{2} \times \mathrm{F}_{3}$ (i.e. Open field x $0.75 \mathrm{ETc} \times 75 \%$ $\mathrm{RDF}$ ) and $\mathrm{E}_{2} \times \mathrm{I}_{3} \times \mathrm{F}_{3}$ (i.e. Open field $\times 0.60$ ETc x $75 \%$ RDF).

\section{Gross monetary returns}

The differences in respect of gross monetary returns were observed due to the various treatments under study. The gross income obtained under different treatments varied from ₹ 31,474/- to3, 28,036/-. The maximum gross monetary returns per $1008 \mathrm{~m}^{2}$ of ₹ 3 , 28,036/- were obtained under the treatment of $\mathrm{E}_{1} \mathrm{I}_{1} \mathrm{~F}_{1}$ (i.e. Polyhouse x 0.90 ETc x $125 \%$ RDF). The minimum gross monetary returns (₹ $31,474 /$ /) were obtained by $\mathrm{E}_{2} \mathrm{I}_{3} \mathrm{~F}_{3}$ (i.e. Open field x 0.60 ETc x $75 \%$ RDF).

\section{Net income}

The net income obtained due to various 
treatments is reported in Table 2. The net income obtained under different treatments varied from ₹ -34,945/- to 1, 79,319/-. The maximum net income of (₹ 1, 79,319/-) was obtained under the treatment of $\mathrm{E}_{1} \mathrm{I}_{1} \mathrm{~F}_{1}$ (i.e. Polyhouse x 0.90 ETc x $125 \%$ RDF) and the minimum net income (₹ -34,945/-) was under $\mathrm{E}_{2} \mathrm{I}_{3} \mathrm{~F}_{3}$ (i.e. Open field $\mathrm{x} 0.60$ ETc $\times 75 \%$ RDF).

\section{Benefit: Cost ratio}

The calculated values of $\mathrm{B}$ : $\mathrm{C}$ ratios in various treatments are shown in Table 2. The B: C ratio obtained under different treatments varied from 0.47 to 2.21 . The maximum B: C ratio of 2.21 was obtained under the treatment of $\mathrm{E}_{1} \mathrm{I}_{1} \mathrm{~F}_{1}$ (i.e. Polyhouse x 0.90 ETc x $125 \%$ RDF), whereas the minimum $\mathrm{B}$ : $\mathrm{C}$ ratio $(0.47)$ was recorded in treatment $\mathrm{E}_{2} \mathrm{I}_{3} \mathrm{~F}_{3}$ (i.e. Open field $\times 0.60$ ETc $\times 75 \%$ RDF). Table 2 Economics of red cabbage production as affected by environmental conditions, irrigation regimes and fertigation regimes.

Table.1 Details of treatments and symbol used

\begin{tabular}{|c|c|c|}
\hline S. No. & Symbol used & Treatments \\
\hline 1 & $\mathrm{~T}_{1}: \mathrm{E}_{1} \times \mathrm{I}_{1} \times \mathrm{F}_{1}$ & Polyhouse x $90 \%$ ETc x $125 \%$ RDF \\
\hline 2 & $\mathrm{~T}_{2}: \mathrm{E}_{1} \times \mathrm{I}_{1} \times \mathrm{F}_{2}$ & Polyhouse x $90 \%$ ETc x $100 \%$ RDF \\
\hline 3 & $\mathrm{~T}_{3}: \mathrm{E}_{1} \times \mathrm{I}_{1} \times \mathrm{F}_{3}$ & Polyhouse x $90 \%$ ETc x $75 \%$ RDF \\
\hline 4 & $\mathrm{~T}_{4}: \mathrm{E}_{1} \times \mathrm{I}_{2} \times \mathrm{F}_{1}$ & Polyhouse x $75 \%$ ETc x $125 \%$ RDF \\
\hline 5 & $\mathrm{~T}_{5}: \mathrm{E}_{1} \times \mathrm{I}_{2} \times \mathrm{F}_{2}$ & Polyhouse x $75 \%$ ETc x $100 \%$ RDF \\
\hline 6 & $\mathrm{~T}_{6}: \mathrm{E}_{1} \times \mathrm{I}_{2} \times \mathrm{F}_{3}$ & Polyhouse x $75 \%$ ETc x $75 \%$ RDF \\
\hline 7 & $\mathrm{~T}_{7}: \mathrm{E}_{1} \times \mathrm{I}_{3} \times \mathrm{F}_{1}$ & Polyhouse x $60 \%$ ETc x $125 \%$ RDF \\
\hline 8 & $\mathrm{~T}_{8}: \mathrm{E}_{1} \times \mathrm{I}_{3} \times \mathrm{F}_{2}$ & Polyhouse x $60 \%$ ETc x $100 \%$ RDF \\
\hline 9 & $\mathrm{~T}_{9}: \mathrm{E}_{1} \times \mathrm{I}_{3} \times \mathrm{F}_{3}$ & Polyhouse x $60 \%$ ETc x 75\% RDF \\
\hline 10 & $\mathrm{~T}_{10}: \mathrm{E}_{2} \times \mathrm{I}_{1} \times \mathrm{F}_{1}$ & Open field x $90 \%$ ETc x $125 \%$ RDF \\
\hline 11 & $\mathrm{~T}_{11}: \mathrm{E}_{2} \times \mathrm{I}_{1} \times \mathrm{F}_{2}$ & Open field x $90 \%$ ETc x $100 \%$ RDF \\
\hline 12 & $\mathrm{~T}_{12:} \mathrm{E}_{2} \times \mathrm{I}_{1} \times \mathrm{F}_{3}$ & Open field x $90 \%$ ETc x 75\% RDF \\
\hline 13 & $\mathrm{~T}_{13}: \mathrm{E}_{2} \times \mathrm{I}_{2} \times \mathrm{F}_{1}$ & Open field x $75 \%$ ETc x $125 \%$ RDF \\
\hline 14 & $\mathrm{~T}_{14}: \mathrm{E}_{2} \times \mathrm{I}_{2} \times \mathrm{F}_{2}$ & Open field x $75 \%$ ETc x $100 \%$ RDF \\
\hline 15 & $\mathrm{~T}_{15}: \mathrm{E}_{2} \times \mathrm{I}_{2} \times \mathrm{F}_{3}$ & Open field x $75 \%$ ETc x $75 \%$ RDF \\
\hline 16 & $\mathrm{~T}_{16}: \mathrm{E}_{2} \times \mathrm{I}_{3} \times \mathrm{F}_{1}$ & Open field x $60 \%$ ETc x $125 \%$ RDF \\
\hline 17 & $\mathrm{~T}_{17}: \mathrm{E}_{2} \times \mathrm{I}_{3} \times \mathrm{F}_{2}$ & Open field x $60 \%$ ETc x $100 \%$ RDF \\
\hline 18 & $\mathrm{~T}_{18}: \mathrm{E}_{2} \times \mathrm{I}_{3} \times \mathrm{F}_{3}$ & Open field x $60 \%$ ETc x 75\% RDF \\
\hline
\end{tabular}


Table.2

\begin{tabular}{|c|c|c|c|c|c|}
\hline $\begin{array}{l}\text { Treatment } \\
\quad \text { No. }\end{array}$ & Treatment & $\begin{array}{l}\text { Cost of cultivation, } \\
\quad ₹ 1008 \mathrm{~m}^{-2}\end{array}$ & $\begin{array}{l}\text { Gross income, } \\
\quad ₹ 1008 \mathrm{~m}^{-2}\end{array}$ & $\begin{array}{l}\text { Net Income, } \\
\text { ₹ } 1008 \mathrm{~m}^{-2}\end{array}$ & $\begin{array}{l}\text { B:C } \\
\text { ratio }\end{array}$ \\
\hline$T_{1}$ & $\mathbf{E}_{1} \times \mathbf{I}_{1} \times \mathbf{F}_{1}$ & 148717 & 328036 & 179319 & 2.21 \\
\hline $\mathbf{T}_{2}$ & $\mathbf{E}_{1} \times \mathbf{I}_{1} \times \mathbf{F}_{2}$ & 148300 & 284366 & 136066 & 1.92 \\
\hline $\mathbf{T}_{3}$ & $E_{1} \times I_{1} \times F_{3}$ & 147889 & 278877 & 130988 & 1.89 \\
\hline $\mathbf{T}_{4}$ & $E_{1} \times I_{2} \times F_{1}$ & 148717 & 275547 & 126830 & 1.85 \\
\hline$T_{5}$ & $E_{1} \times I_{2} \times F_{2}$ & 148300 & 271687 & 123387 & 1.83 \\
\hline$T_{6}$ & $\mathbf{E}_{1} \times \mathbf{I}_{2} \times \mathbf{F}_{3}$ & 147889 & 243627 & 95738 & 1.65 \\
\hline $\mathbf{T}_{7}$ & $\mathbf{E}_{1} \times \mathbf{I}_{3} \times \mathbf{F}_{1}$ & 148717 & 195645 & 46928 & 1.32 \\
\hline $\mathbf{T}_{8}$ & $\mathbf{E}_{1} \times \mathbf{I}_{3} \times \mathbf{F}_{2}$ & 148300 & 184176 & 35876 & 1.24 \\
\hline$T_{9}$ & $E_{1} \times I_{3} \times F_{3}$ & 147889 & 142032 & -5856 & 0.96 \\
\hline$T_{10}$ & $\mathbf{E}_{2} \times \mathbf{I}_{1} \times \mathbf{F}_{1}$ & 67247 & 77858 & 10611 & 1.16 \\
\hline$T_{11}$ & $E_{2} \times I_{1} \times F_{2}$ & 66830 & 72347 & 5517 & 1.08 \\
\hline$T_{12}$ & $E_{2} \times I_{1} \times F_{3}$ & 66419 & 67101 & 683 & 1.01 \\
\hline $\mathbf{T}_{13}$ & $\mathbf{E}_{2} \times \mathbf{I}_{2} \times \mathbf{F}_{1}$ & 67247 & 66525 & -721 & 0.99 \\
\hline$T_{14}$ & $\mathbf{E}_{\mathbf{2}} \times \mathbf{I}_{\mathbf{2}} \times \mathbf{F}_{2}$ & 66830 & 61217 & -5613 & 0.92 \\
\hline$T_{15}$ & $\mathbf{E}_{\mathbf{2}} \times \mathbf{I}_{\mathbf{2}} \times \mathbf{F}_{3}$ & 66419 & 54465 & -11954 & 0.82 \\
\hline$T_{16}$ & $E_{2} \times I_{3} \times F_{1}$ & 67247 & 43171 & -24076 & 0.64 \\
\hline$T_{17}$ & $\mathbf{E}_{\mathbf{2}} \times \mathbf{I}_{3} \times \mathbf{F}_{2}$ & 66830 & 37570 & -29260 & 0.56 \\
\hline$T_{18}$ & $\mathbf{E}_{2} \times \mathbf{I}_{3} \times \mathbf{F}_{3}$ & 66419 & 31474 & -34945 & 0.47 \\
\hline
\end{tabular}

In conclusions, the maximum $\mathrm{B}$ : $\mathrm{C}$ ratio of 2.21 was obtained under polyhouse condition with drip irrigation @ 0.90 ETc and fertigation @ 125\% RDF and the minimum in open field condition with drip irrigation @ 0.60 ETc and fertigation @ 75\% RDF. Hence, the adoption of polyhouse with irrigation regimes of 0.90 ETc and fertigation regimes of $125 \%$ of RDF was found to be best amongst all other treatments, having maximum B: $\mathrm{C}$ ratio and maximum net income, for the production of red cabbage.

\section{References}

Braulio, I. A., A. B. Rezende, C. Filho, A. P. Barros, R. Q. Porto Diego and M. I. Martins. 2010. Economic analysis of cucumber and lettuce intercropping under greenhouse in the winter-spring.
Annals of Brazilian Academy of Sciences, 83(2): 705-717.

Kumar, R. and S. Kumar. 2017. Effect of irrigation levels and frequencies on growth, yield and economics of capsicum production under naturally

ventilated polyhouse. Dr. Y. S. Parmar University of Horticulture and Forestry, Solan, HP. Vegetable Science; 44 (1).

Laate, E. A. 2013. The economics of production and marketing of greenhouse crops in alberta. Economics and Competitiveness Division, Agriculture and Rural Development, Alberta, Canada.

Murthy, D. S., B. S. Prabhakar, S. S. Hebbar, V. Srinivas and M. Prabhakar. 2009. Economic feasibility of vegetable production under polyhouse: A case study of capsicum and tomato. Section 
of Economics and Statistics Indian India. Journal of Horticultural Sciences, Institute of Horticultural Research, Vol. 4 (2): 148-152.

Hesarghatta Lake Post, Bangalore,

\section{How to cite this article:}

Vishal Pandey and Firake, N. N. 2020. Economic Viability of Red Cabbage Production under Varying Environment and Ferti-Irrigation Regimes. Int.J.Curr.Microbiol.App.Sci. 9(04): 19651969. doi: https://doi.org/10.20546/ijcmas.2020.904.234 